\title{
（MS14）分子集合における,対称性，非対称性, およびキラリティー
}

\author{
副座長: 大阪大学大学院工学研究科生命先端工学専攻 久木一朗
}

\section{Ichirou HISAKI: (MS14) Symmetry, Asymmetry and Chirality in Molecular Aggregation}

昨年の夏に開催されたIUCr2008 では，ワシントン大学 の Werner Kaminsky 教授とともに, マイクロシンポジウム 14 (MS14) 「Symmetry, asymmetry and chirality in molecular aggregation」の chair を仰せつかった. 日本で開催さ れるのは実に 36 年ぶりというこの記念すべき大会に, chair として参加することができたのは大変光栄なことで ある. 本MS はそのタイトルどおり，結晶を始めとする分 子集合の対称性, キラリティーに焦点を当てて企画された. 誤解を恐れずに言うと, 分子結晶はこの世の中で最も美 しい超分子集合体の 1 つである. 例えば一辺 $0.2 \mathrm{~mm}$ ほど の単結晶であったとしても，1015個を超える分子が非共 有結合性の相互作用によって互いの分子を認識し合って 整然と配列している. そのような分子の集合体はほかにな い.このような場では，条件さえ揃えば，たとえ 1 分子の キラリティーや小さな分子の構造変化であっても, 多くの 分子が同調することによって単結晶というマクロなスケ ールで，それらが目視できるほどになる。

結晶の大きな特徴の 1 つとて, 対称性の高いアキラルな 分子であってもその結晶はキラリティーをもつことができる という点が挙げられると思う. 結晶はその他の分子集合に 比べて非常に密に分子が充填されているため, 分子の運動 が束縛されている (近年, 結晶中における分子の動的挙動 は活発に報告されているが, それでもほかの系と比べると その運動は束縛されていると言える). したがって, 分子 の配座が固定されキラルなコンフォメーションをとること によって, アキラルな分子であってもキラリティーが発生し 得る.さらに1分子ではアキラルな構造であっても, 複数 の分子の位置関係によってはその分子集合にはキラリテ

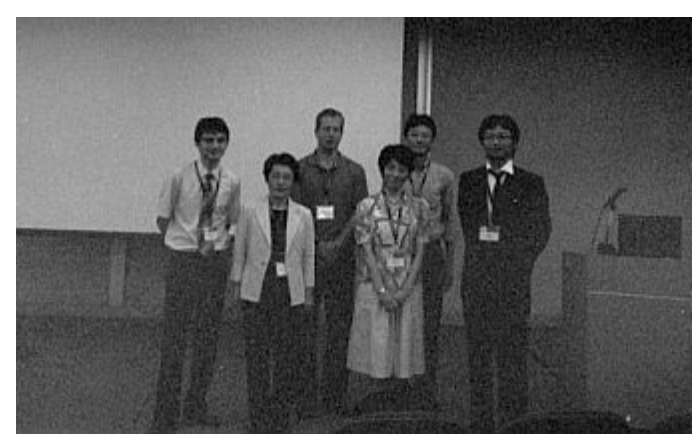

日本結晶学会誌 第 51 巻 第 1 号 (2009)
イー (超分子キラリティー) が発生する.このため, アキラ ルな分子を用いた結晶化によって, 対称の破れ (symmetry breaking) を発生させることができる.アキラルな分子が 作るキラルな分子集合に関して例を挙げると, 私が研究対 象の 1 つにしている 21 らせん軸をもつ結晶構造がまさに その典型的な例である. 21 らせん対称軸を含む結晶は, Cambridge Structural Database に登録されている 397000 件 に上る結晶構造のうちの 70 \%を占める約 280000 件に上 る (2007 年 1 月時点調べ). このうち, キラルで非中心対称 性の空間群である $P 2_{1}$ は, 24000 件近くもあり, これらの キラルな構造とその構造が与える物性には興味が尽きな い.これらのことは周知の事実ではあるが, 本 MS におい ては重要な点に思われたのであえて言及させていただいた。

キラルな結晶は, 不斉な空間あるいは表面を提供する不 斉源として機能し得る. あるいは, 結晶中でのキラルなコ ンフォメーションの記憶をもった分子による不斉反応が 期待できる. また新奇な集合体の構築, 応用とともに, 固 相での分子集合のキラリティーをどのように同定・評価 すればよいか, その方法の開発も合わせて重要である. 以 上の観点から, 本MS では, 結晶を始めとする幅広い分子 集合における超分子キラリティーについて, 第一線の先生 方に下記のような演題で講演をいただいた。

ご講演いただいた先生方（講演順）

黒田玲子先生

Chirality Realized Only in the Crystalline State : Inorganic and Organic Compounds

Dr. V. S. Minkov

Structure-Property Relationship in the Crystals of Chiral Amino Acids and Their Racemic Counterparts 小島秀子先生

Chiroptical Properties of $\mathrm{N}$-benzoylglycine Crystals Prof. C. H. Gorbits

A Solution to the Problem Why Chiral Hydrophobic Amino Acids form Crystals with $Z^{\prime}=2$ 坂本昌巳先生

Control of Chirality by Spontaneous Crystallization and Absolute Asymmetric Synthesis in Fluid Media. 
シンポジウムでは大変活発な議論が行われ, 本 MS は 結晶のみならず分子集合のキラリティーに携わる科学者 にとって大変有意義であったと確信している. 文末ではあ
るが,このようなマイクロシンポジウムを開催する機会を 与えていただいたIUCr2008の企画運営に携わられた皆 様, ご講演いただいた先生方に厚く御礼申し上げる。

\title{
結晶化によるキラリティーの制御と均一系での 絶対不斉合成の開発 (MS14)
}

\author{
講演者：千葉大学大学院工学研究科 坂本昌巳
}

\section{Masami SAKAMOTO: Control of Chirality by Spontaneous Crystallization and Absolute Asymmetric Synthesis in Fluid Media (MS14)}

有機化合物が形成する結晶中には，分子の構造や配座， 分子配列, キラリティーなどの多くの情報が記録されてい る. その情報は立体選択的反応户絶対不斉合成, 分子認 識, 光学分割などに利用されている.われわれは特にアキ ラルな基質の結晶化により発現するキラリティーを利用 した絶対不斉合成に興味をもち数多くの結晶相反応を報 告してきた.この現象は 1960 年代後半に見出され, 分子 間 $2+2$ 光付加反応の例を中心に開発され，これまでに約 30 の反応系が報告されている.われわれは分子内固相光 反応を中心に多くの反応例を見出している.

このキラル結晶を用いた絶対不斉合成は, ほとんどが固 相光反応を利用して結晶中で分子中に新たな不斉中心を 作ることによって達成されている. したがって, この手法 を固相光反応以外の固液や固気, 固体同士の反応に応用し た場合には, 反応の進行に伴い結晶状態が崩壊し結晶のキ ラリティーも消失してしまうために, 利用できる反応は限 られていた. 例外的にいくつかの反応が見出されてはいる が生成物の光学純度はいずれも低い。もし, 結晶状態が崩

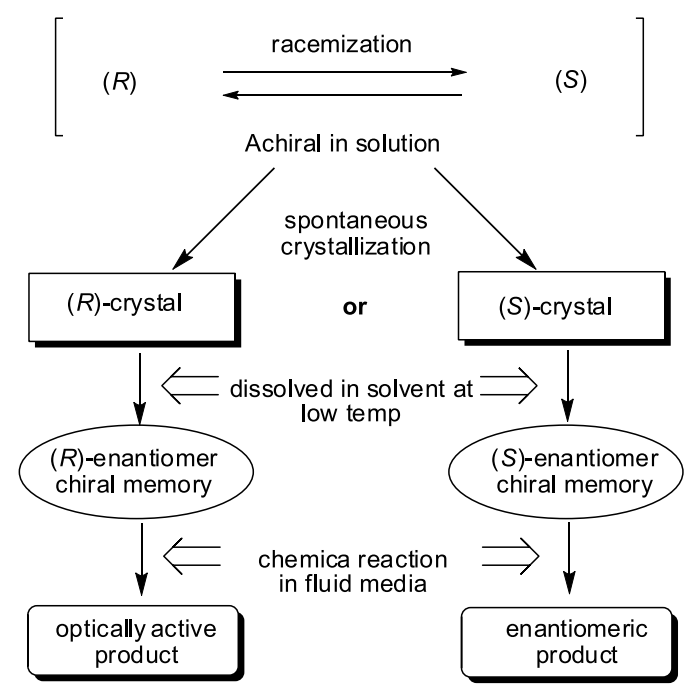

図1 キラル結晶を用いた均一系での絶対不斉合成. (Absolute asymmetric reaction using chiral crystals in fluid media.)
壞した後も結晶化により発現した分子のキラリティーを 保持することが可能であれば, キラル結晶を利用した絶対 不斉合成を膨大な化学反応に応用し展開することが可能 となる (図 1).

われわれはすでに, キラル結晶から誘導したキラル分子 配座を利用して均一系での絶対不斉合成に成功し, 2-ベン ゾイルベンズアミドと $\alpha$ ケ酸イミドのカルボニル基へ の有機リチウム試薬の不斉求核付加反応で $80 \%$ ee 以上の 光学純度での不斉合成を報告した.1,22) 今回の講演では, 近 年われわれが開発した不斉結晶から誘導した分子キラルメ モリーを利用した均一系での分子間光付加反応, 求核付加 反応, ラセミ体アミンの速度論的分割の例を紹介する。

結晶を構成する分子はアキラルであるが, 結晶を溶液と したときに結晶中の分子構造をある程度の時間保持する 機能を備えた分子を考えたときに, 多くの誘導体を合成で きることや反応に対する安定性を考慮して芳香族アミド を母核とする分子を選択した，さらに，芳香環とアミド基 間の軸回転がラセミ化に相当する分子をデザインした (図2). 芳香環とアミドカルボニル基間の回転障壁エネル ギーは周囲の置換基の立体的なサイズにより制御可能で ある.また,アミドの $(\mathrm{C}=\mathrm{O})-\mathrm{N}$ 間の結合は約 $20 \sim 24$ $\mathrm{kcal} / \mathrm{mol}$ 程度であり,この結合が回転すれば芳香環とアミ ドカルボニル基間も回転するために, 容易にラセミ化のエ ネルギーを制御できるからである. 今回は図2のナフトア ミド1とクマリンカルボキシアミド 2 を用いた均一系絶 対不斉合成例を紹介する.いずれの基質も室温では芳香環 とアミド基間の回転により容易にラセミ化が起こりアキ ラルな基質である.

これらの基質は通常の手段で分割することはできない が結晶化により不斉が発現し, 結晶化の条件を整えること により，1つのフラスコ内をすべて同じ鏡像異性体の結晶 に偏らせることが可能である.ささらに, これらのラセミ化 はそれほど速くはなく, 結晶を低温の有機溶媒に溶解した 場合には，ある程度の時間, 結晶中に発現した不斉な配座 を記憶できる.ラセミ化の半減期は, 溶媒の温度や極性, 


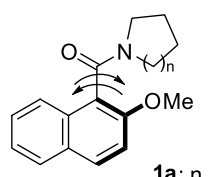

(R)-1 $\begin{array}{ll}\text { 1a: } & \mathrm{n}=1 \\ \mathrm{~b} & \mathrm{n}=2\end{array}$

$(S)-1$

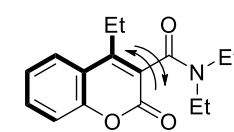

$(R)-2$

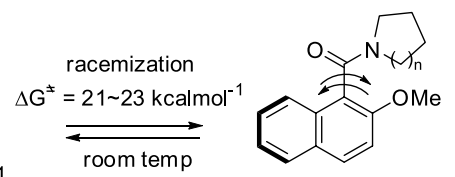

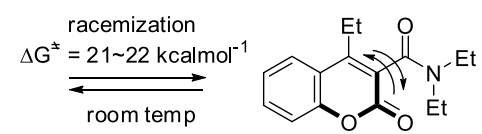

(S)-2
図2 軸回転による芳香族アミドのラセミ化.

(Racemization of aromatic amides owing to the bond rotation.)

水素結合能に大きく影響を受け，例えば1aは，THF中

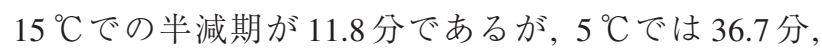
$\mathrm{MeOH}-\mathrm{THF}$ の等量混合溶媒中では $15{ }^{\circ} \mathrm{C} て ゙ も 128$ 分の半減 期となる. 1bや 2 もほほ同じラセミ化の活性化エネルギ 一を有する.

これらの結晶中の光学活性な分子配座を, 均一系での化 学反応により生成物の不斉中心へと不斉転写し光学活性 を得ることに成功した. 例えば, 9-シアノアントラセン (9$\mathrm{CN})$ を含む一 $20{ }^{\circ} \mathrm{C}$ の $\mathrm{THF}$ の溶液に $\mathbf{1 b}$ のキラル結晶（結 晶空間群 $\left.P 2{ }_{2} 2_{1} 2_{1}\right)$ を溶解し, 高圧水銀灯にて光照射した.

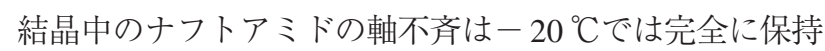
されておりラセミ化は起こらない. 励起された 9-CNが結 晶から溶出してきた光学活性なナフトアミドの立体的に 空いているアミドカルボニル基側から選択的に $4+4$ 付 加反応し, 95 \% ee の光学活性な付加物 3 を定量的に与え た（スキーム 1). 反応溶媒をラセミ化が起こりにくい $\mathrm{MeOH}$ を含む THF 溶液にすると, $20{ }^{\circ} \mathrm{C}$ の温度でさえも $88 \%$ ee の不斉光付加反応が達成できた. 不斉結晶のキラ リティーを均一系へと誘導しキラルメモリーとして利用 することで, 固相光反応ではなし得ないこのような不斉反 応の手法を開発できた.3)

このキラルメモリーは種々の反応に応用可能である. 1a のキラル結晶（結晶空間群 $P 22_{2} 2_{2} 2_{1}$ ) から誘導したキラル メモリーと $t$-BuLi との $\mathrm{S}_{\mathrm{N}} \mathrm{Ar}$ 反応では2-位のメトキシ基を 嵩高い $t$ - $\mathrm{Bu}$ 基に置換することで安定な軸不斉化合物へと 変換できた.このときの生成物の収率は $97 \%$ \%あり, 光学 純度は $85 \%$ eeであった.4) さらに,リチウムアミドとの $\mathrm{S}_{\mathrm{N}} \mathrm{Ar}$ 反応では, ラセミ体アミンを速度論的に分割するこ とができた. 例えば，ラセミ体の2-メチルピロリジンと BuLiによりリチウムアミドとし，この溶液に $1 \mathrm{a}$ の不斉結 晶を加えてー $20{ }^{\circ} \mathrm{C} に て 反$ 応させた. 5 倍等量のリチウム アミドを用いた場合には $85 \%$ ee の 2-アミノ生成物を $99 \%$ の収率で得ることができ, リチウムアミドを 2 倍等 量まで減少させた場合でも，添加物を加えることにより， 高い不斉収率を達成できた。

クマリンカルボン酸アミド 2 の不斉結晶(結晶空間群 日本結晶学会誌 第 51 巻 第 1 号 (2009)
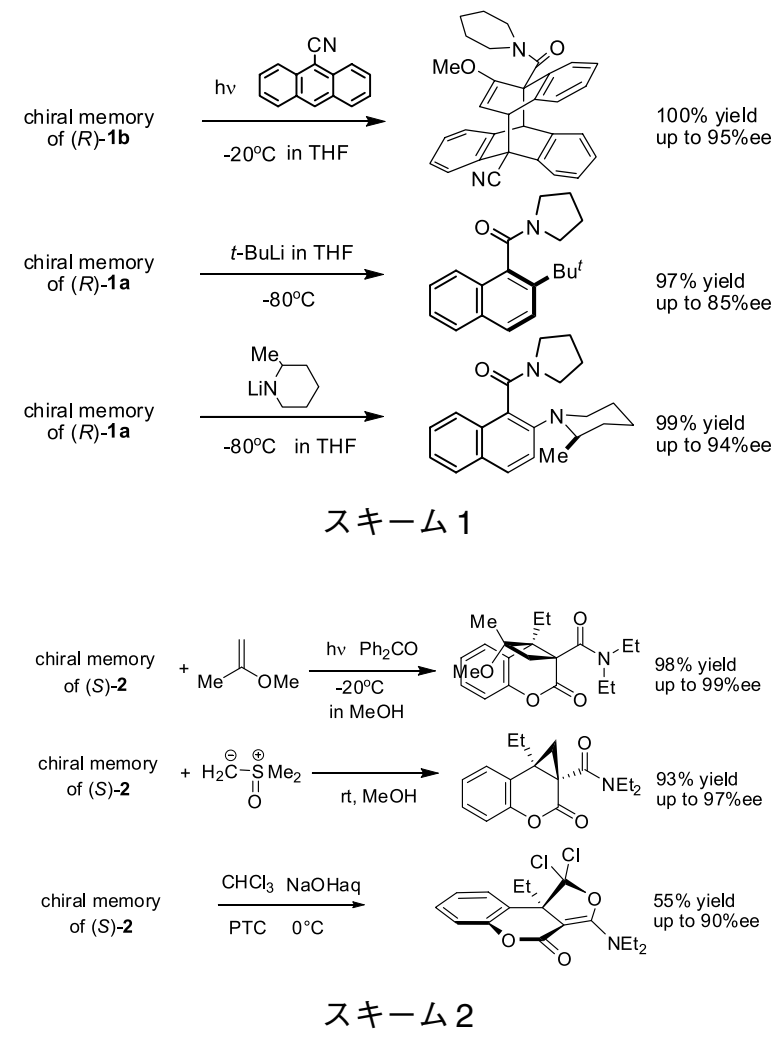

$\left.P 2_{1} 2_{1} 2_{1}\right)$ を用いた場合にも種々の不斉反応に応用するこ とができた (スキーム 2).この基質は一重項励起状態では ラセミ化してしまうが三重項励起状態からはラセミ化す ることなく分子間 $2+2$ 付加反応が進行する.メトキシプ ロペンやエチルビニルエーテルなどの電子豊富なアルケ ンのメタノール溶液に三重項増感剤としてベンゾフェノ ンを加え， $-20{ }^{\circ} \mathrm{C} に て 2$ の不斉結晶を溶解して光照射し た、いずれのアルケンを用いた場合でも 97 ～99 \% eeの シクロブタン体をほぼ定量的に得ることができた.5)

さらに, 2 のキラルメモリーを利用したイリドとの反応 ではシクロプロパンを $97 \%$ ee で合成し, ジクロロカルベン との反応ではジヒドロフランの縮重した化合物を 90 \% ee で不斉合成することに成功した。

以上のように, キラル結晶を利用した新しい絶対不斉合 成手法を開発し, キラル結晶化により発現した不斉を均一 系でのさまざまな反応を用いて生成物にキラル転写する ことに成功した.

\section{文 献}

1) M. Sakamoto, T. Iwamoto, N. Nono, M. Ando, W. Arai, T. Mino and T. Fujita: J. Org. Chem. 69, 942 (2003).

2) M. Sakamoto, S. Kobaru, T. Mino and T. Fujita: Chem. Commun. 1002 (2004).

3) M. Sakamoto, A. Unosawa, S. Kobaru, A. Saito, Y. Kasashima, T. Mino and T. Fujita: Angew. Chem.Int. Ed. Engl., 44, 5523 (2005).

4) M. Sakamoto, A. Unosawa, S. Kobaru, K. Fujita, T. Mino and T. Fujita: Chem. Commun. 3586 (2007).

5) M. Sakamoto, M. Kato, Y. Aida, K. Fujita, T. Mino and T. Fujita: J. Am. Chem. Soc. 130, 1132 (2008). 